\title{
The Development of Interactive Multimedia on Science Learning Based Adobe Flash CS6
}

\author{
Luh Sukariasih ${ }^{1, a^{*}}$, Erniwati1 ${ }^{1, b}$, and Agus Salim ${ }^{1, c}$ \\ 1Department of Physics Education, Faculty of Teacher Training and Education, University of Halu Oleo, Sulawesi Tenggara, 93232, Indonesia \\ a* Luhsukariasih@uho.ac.id; b Erniwati@uho.ac.id; c Agussalim@gmail.com \\ ${ }^{*}$ Corresponding Author \\ Whatsapp Number [ +6285218232800]
}

How to Cite: Sukariasih, L., Erniwati, E., \& Salim, A. (2019). The Development of Interactive Multimedia on Science Learning Based Adobe Flash CS6. International Journal for Educational and Vocational Studies, 1(4), 322-329

\section{ARTICLE HISTORY}

Received: 15 April 2019

Revised: 16 June2019

Accepted: 12 July 2019

KEYWORDS

Science Learning;

Multimedia Interactive;

Adobe Flash CS6;

Education;

\begin{abstract}
The purpose of this study to to produce multimedia of science learning in the topic of pressure the circulatory system and respiratory system in humans for students of junior high school class of VIII. In this study uses a Research and Development model that refers to the model of Analysis, Design, Development, Implementation, and Evaluation (ADDIE). In the phase of analysis; a needs analysis, material analysis, and analysis of the level of ability and characteristics of the aim users carried out. Design Phase: create flowcharts and storyboards. At the stage of development, multimedia made. The phase of Implementation, multimedia that has been made validated by experts and limited trials. In the phase of evaluation; at this stage, the multimedia that has been implemented thoroughly evaluated. The evaluation results used to see the level of achievement linked the objectives set at the beginning of the program-data collection techniques used in the form of questionnaires. The data sources in this study consisted of 2 material experts, four media experts, two learning experts, and tested limited to 2 teachers and 18 students from junior high school 8 Kendari. The expert trial results stated that Adobe Flash CS6-based the multimedia of Science learning on pressure material in the circulatory and respiratory systems in humans for students of Class VIII junior high school was under the design, and the material included inappropriate used as science learning multimedia. The results of a limited trial show that the multimedia of science learning in the material of pressure in the circulatory system and the respiratory system in humans is worthy used as a multimedia learning science.
\end{abstract}

This is an open access article under the CC-BY-SA license.

\section{INTRODUCTION}

Multimedia has successfully used in learning at various levels of education and has brought various benefits, especially in Indonesia to make children's learning process more smoothly (Othman \& Wan Ahmad Jaafar Wan Yahaya, 2015). Multimedia applications can present students with real-world experience and make possible to register content in different contexts (Shank, 2008). One of the factors that support learning is the media used. If the learning media have chosen correctly, the continuity of the learning process can run optimally (Ampera, 2017). One of the lessons that require the use of multimedia is science learning.

Science is a science that develops from experience of natural phenomena and interactions that occur in them. Science can apply in lives such as respiration events, blood pressure, submarines, hot air balloons, hydraulic brakes, bridge pots. Thus science is human knowledge of natural phenomena and material obtained by observation, experimentation, or trials based on human observations. Science is also science related to how to find about natural phenomena, and science is not only the knowledge of an accumulation of knowledge in the form of facts, concepts or principles but also a process of discovery. The shows that science learning is a science that must learn through direct observation (Safitri et al., 2014).

But, the facts in the field show that some teachers still use the teaching method in delivering learning material. In the delivery of learning materials have different characteristics that not all right to use the teaching method in the delivery of the material (Muthmainnah \& Imran, 2016). Factors revealed Muthmainnah \& Imran (2016) conclusions that the need for innovation in the learning process. One is the media making learning appropriate to the characteristics of the material to be delivered. According to Gagne, Wager, Golas, Keller, \& Russell (2005) states that media are various types of components in the student environment that can attract students to learn. According to Briggs \& Sommefeldt (2002) states that instructional media such as books, movies, video. 
The use of multimedia in science learning can help students solve problems and can improve students' understanding of concepts (Fayanto, Sulisworo \& Fathan, 2019 ) - the role of multimedia in science teaching very supportive in the success of student learning outcomes. The presence of multimedia can help teachers explaining the phenomenon of science, which mostly abstract and requires teaching aids as a way to eliminate abstractions, and students can understand the concept of science well and correctly. The use of multimedia can help learning science so that the delivery of concepts becomes more meaningful (Iwan \& Suyatna, 2018). Next, According to (Putra, Widodo, \& Jatmiko, 2016) that learning using visual aids is a series of activities to convey subject matter that aims provide opportunities for students actively learn that students can gain knowledge and develop psychomotor skills and foster the creativity of students to solve problems faced.

One of the multimedia used in science teaching is Adobe Flash CS6. One application that familiar to ears and often used to present material is the application of PowerPoint. But with the limitations of the PowerPoint application in making a complex animation, then researchers prefer the Adobe Flash CS6 application because of this application equipped with various kinds of supporting items in creating an animation. The reason the researchers amplified from the opinions expressed by Chen, Wang, \& Wu (2009) used Adobe flash player CS6 as the principal software in developing this topic because of the output format small streaming media, which has a significant advantage during information delivery. Adobe flash player CS6 also very interactive. It can be integrated with much other software and expanded upon by many plug-ins. Besides, the language and database are stronger than the previous version after several updates; all this can mean that Adobe flash player CS6 can achieve uniqueness and interactive courseware.

Some researchers include having used Adobe flash player (Perdiansyah, Supriyadi, \& Astra, 2015) reported that learning media using Adobe Flash CS6 could improve science process skills of class XII students in magnetic field material. While Rezeki (2018) stated that Adobe Flashbased learning media could increase students' learning motivation in class XI in inverse function material. Similarly, Astatin \& Nurcahyo (2016) Adobe Flash-based learning media can improve the conceptual understanding of students of class XI nervous system material while (Aji et al., 2018; Saselah, Amir, \& Riskan, 2017) reported that the use of multimedia based on Adobe flash player in learning is very feasible to use in learning.

Therefore researchers interested in developing interactive multimedia using adobe flash CS6 on pressure metrics in the circulatory system and respiratory system. The purpose of this study to develop multimedia learning, especially in science learning that can help students and teachers understanding concepts related to science topics.

\section{MATERIALS AND METHODS}

In this study uses Research and Development design that refers to the ADDIE model. The design of this study includes five stages, namely, Analysis, Design, Development, Implementation, and Evaluation. For more details, see in Figure 1.

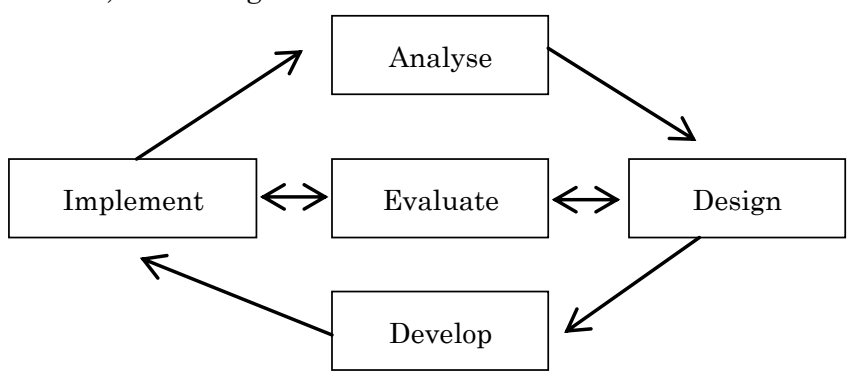

Figure 1. Design ADDIE (Branch, 2009)

This research limited to the development stage of interactive multimedia using adobe flash CS6 on the topic of science (The pressure on the circulatory system and respiratory system in humans). The study conducted in the eighth-grade junior high school in Kendari with a limited test of products in class VIII1 and VIII2, which amounted 18 students.

The data analysis technique used qualitative data analysis, which consists of data reduction, data presentation, and conclusion drawing. Data obtained from observations and interviews conducted in school, then summarized and concluded. From the results of the analysis, the things needed in the development of multimedia learning obtained.

The research instrument used questionnaires and question sheets. Furthermore, in the questionnaire a multilevel scale used wherein each question, the validator gives a score for the aspects asked from the multimedia learning choice categories for validation questionnaires are: (1) scale 1, if the assessment of learning multimedia is not very good / very not in accordance with the assessment criteria; (2) scale 2, if the assessment of learning multimedia is not good / less in accordance with the assessment criteria; (3) scale 3 , if the assessment of multimedia learning is good / in accordance with the assessment criteria; and (4) scale 4, if the assessment of multimedia learning is very good / very in accordance with the assessment criteria (Arikunto, 2009). The formula calculates the percentage of each indicator on the questionnaire using equations (1).

$$
P=\frac{\Sigma X}{n} \times 100 \% \quad N A=\frac{\Sigma F}{n}
$$

Where,

$P=$ percentage score; $N A=$ final score; $\sum X=$ total score;

$N=$ maximum score; $n=$ many questions

To determine the level of validity and practicality of multimedia learning developed, it will use the 
qualification criteria based assessment (Arikunto, 2009) shown Table 1.

Table 1. Criteria of Practical And Validity

\begin{tabular}{ccc}
\multicolumn{3}{c}{ (Arikunto, 2009) } \\
\hline Persentase (\%) & Level of validity & Description \\
\hline $76-100$ & Valid & Worthy \\
$50-75$ & Valid enough & Enough \\
$26-50$ & Less Valid & Less \\
$<26$ & Invalid & Not \\
\hline
\end{tabular}

\section{RESULTS AND DISCUSSIONS}

Interactive multimedia is an electronic system that sent by a computer allows users to control, combine and manipulate various types of media, such as text, sound, video, computer graphics, and animation (Augustyn, 2019). Research is a development research by studying science lessons. The ADDIE stage consists of Analysis, Define, Design, Implementation, and Evaluation as described below.

\section{Stage of Analysis}

In the analysis phase of the development of Adobe Flash CS6 science-based learning multimedia on pressure material in the circulatory and respiratory systems in humans for students of class VIII SMP. At this stage, a needs analysis, material analysis, analysis of the level of ability and characteristics of the intended use carried.

\subsubsection{Phase Requirements Analysis}

Computer applications also help an educator in the learning process at school. But in some schools in Kendari still not using the computer as a learning medium. Because they tend to use computers as a tool to help school administrators, as a tool for typing school exam questions. Caused by the lack of knowledge in the field of technology.

\subsubsection{Phase Anaysis of Topic}

Formulation of learning material based on teaching materials and school syllabus. . Not all words in teaching materials incorporated into the learning media, this is done to facilitate understanding without reducing the meaning of the sentence.

\subsubsection{Phase of Charateristic Analysis and User Objektivitas}

The next step is to consider the characteristics of students, the characteristic analysis to analyze students globally. Based on the cognitive abilities and habits of students adjusted to their age by criteria: (a) Students at the age of 12-14 years are classified as formal operational stages, namely with the ability to think abstractly and purely towards the development of adult characteristics, and have been able to solve problems through systematic experiments; (b) Learners will be interested in images, sounds, moving animations and simulations with a look that suits their preferences in adolescence.

\section{Stage of Design}

This stage includes the process of designing the items to be presented, a compilation of material manuscripts, compilation of material delivery channels in the form of flowcharts, making storyboard media, and collecting materials needed in media development. First appearance of learning media design.

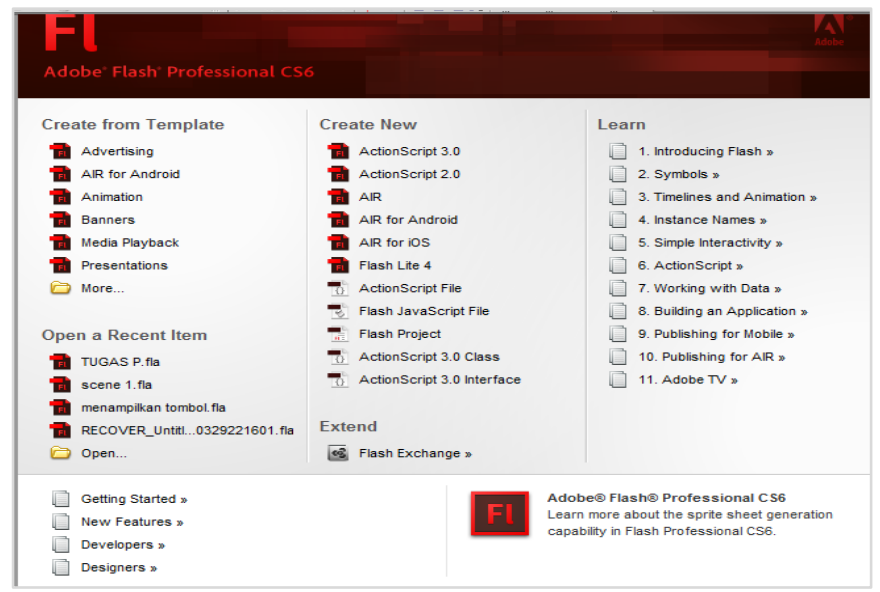

Figure 2. Display start page Adobe Flash Professional CS6

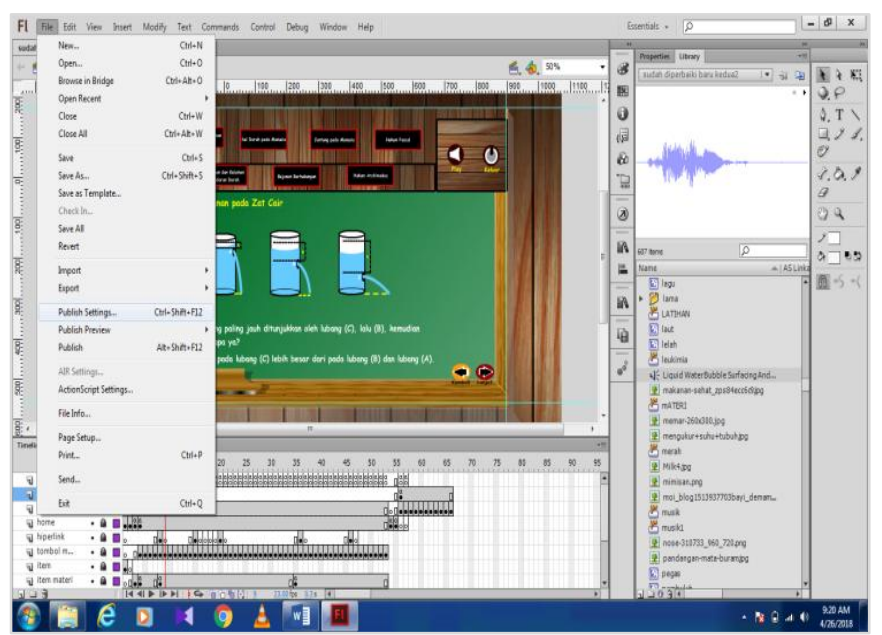

Figure 3. The main window display Adobe Flash CS6

\section{Stage of Development}

This stage consists of creating multimedia using Adobe Flash CS6 software. At this stage also made some supporting details in the media, such as animations and simulations. Making development of Adobe Flash CS6based multimedia of Science learning on pressure material in the circulatory and respiratory system in humans for the student of the class VIII junior high school. Making all multimedia contents tail to the storyboard that has made. The development phase described as follows: 


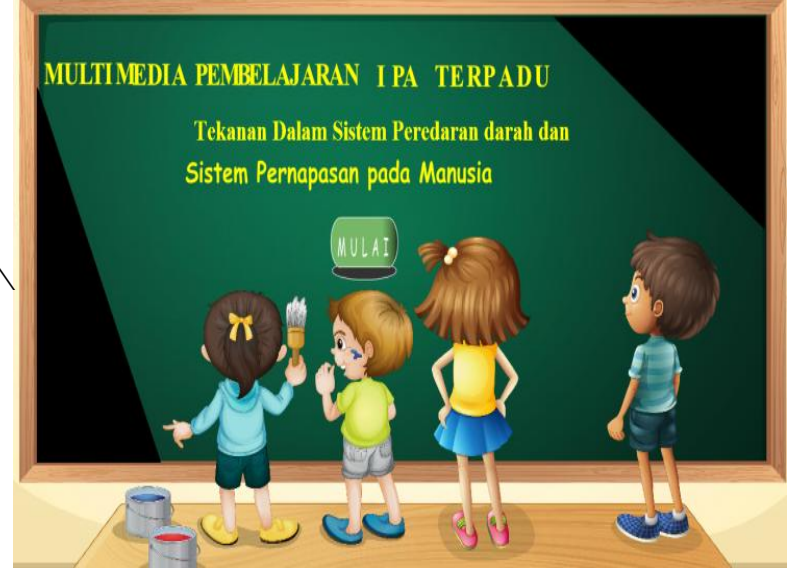

Figure 4 The display of initial multimedia science learning pressure in the circulatory system and respiratory system in humans

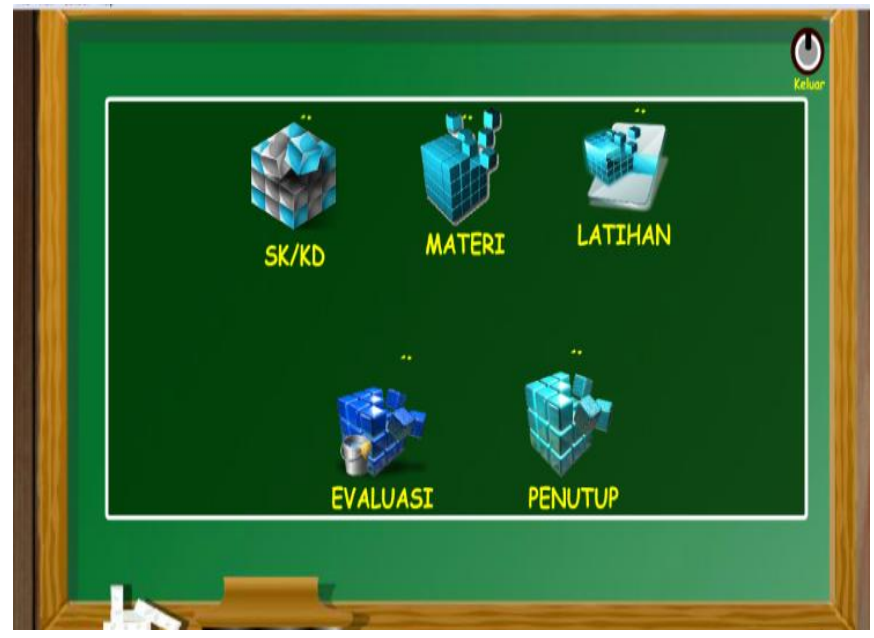

Figure 5. Display of the main menu of multimedia learning in the topic of pressure in the circulatory system and the respiratory system in humans

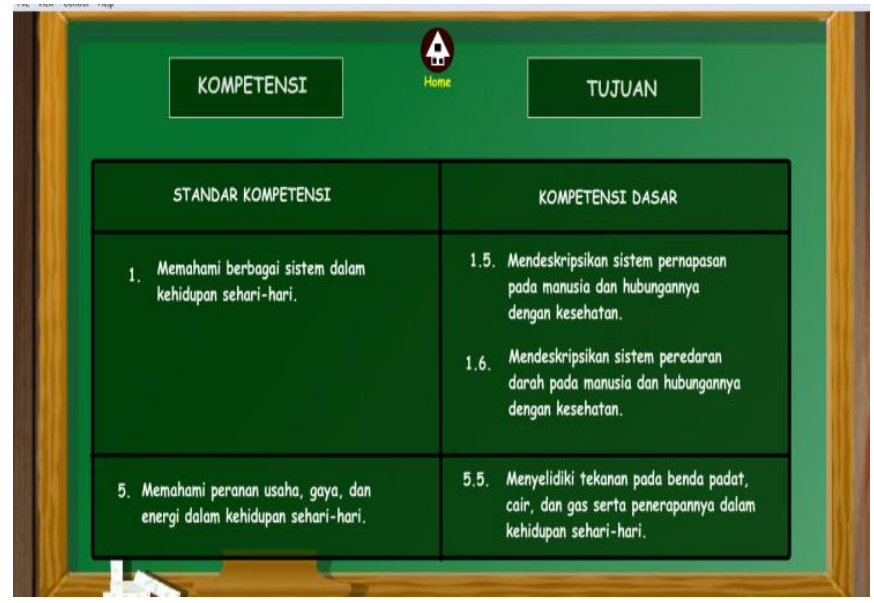

Figure 6. Display the menu of multimedia competencies

for science learning in the topic of pressure in the circulatory system and the respiratory system in humans

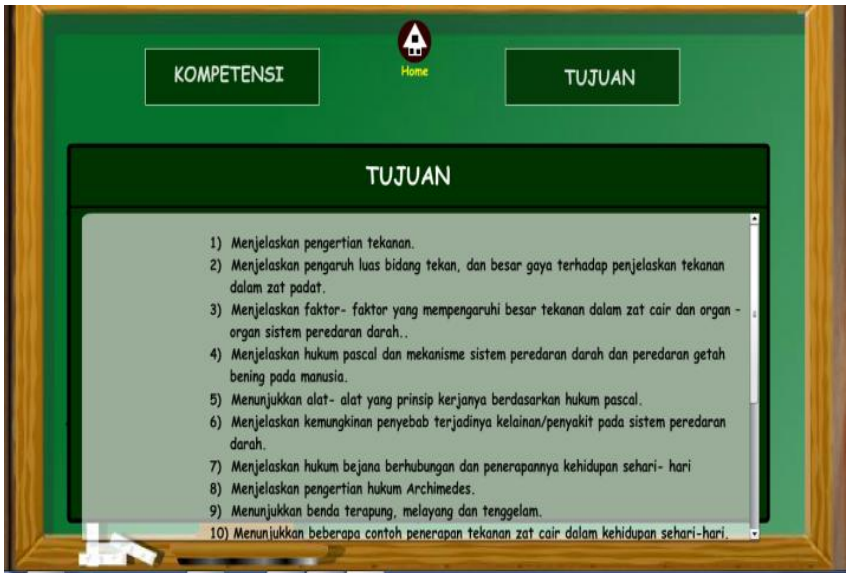

Figure 7. Display the menu of learning objectives for material pressure in the circulatory system and the respiratory system in humans

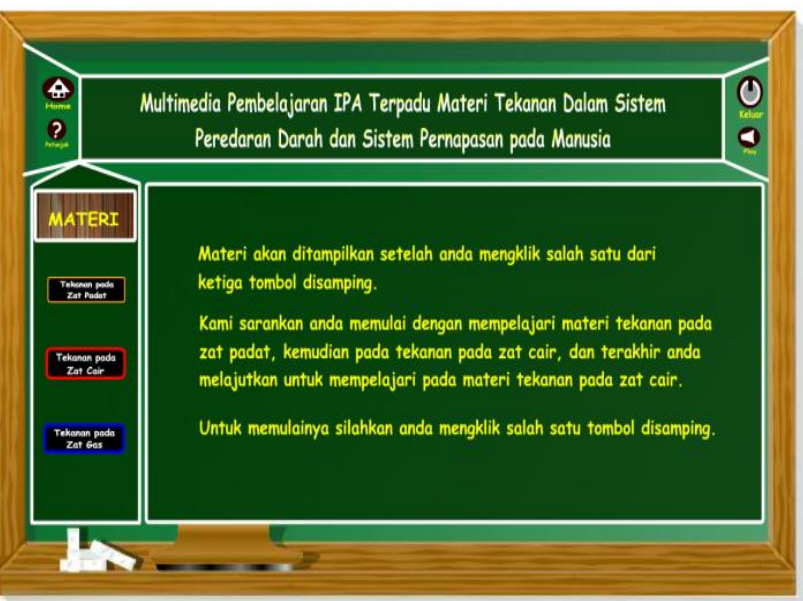

Figure 8. Display the contents of the material menu using multimedia applications learning material pressure in the circulatory system and the respiratory system in humans.

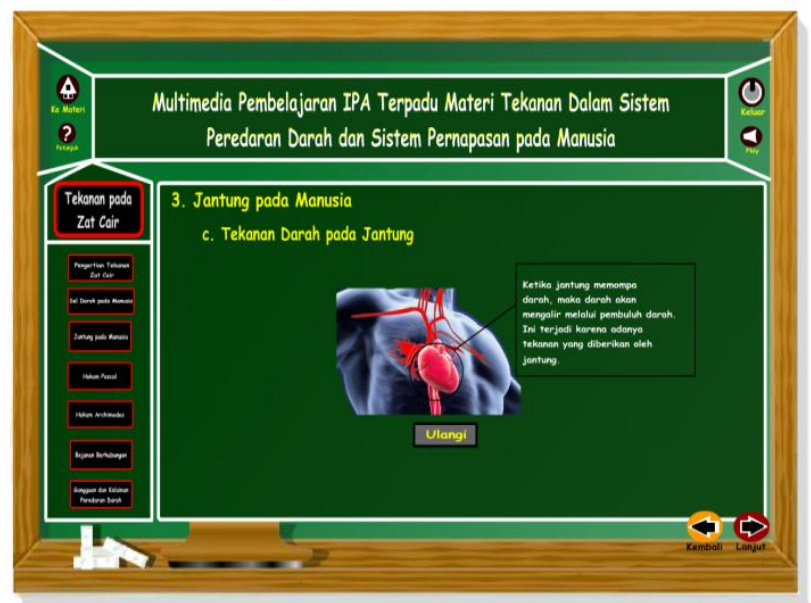

Figure 9 Display the contents of the multimedia material for learning about pressure material in the circulatory system and the respiratory system in humans. 


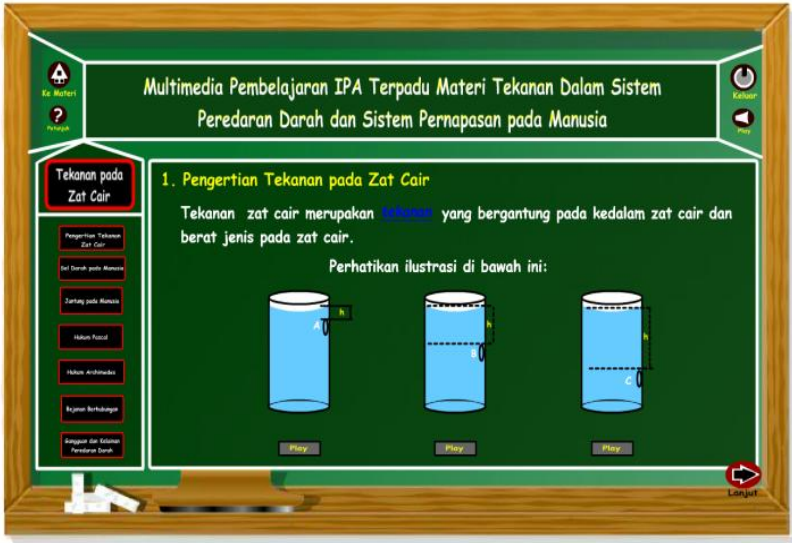

Figure 10 Display the contents of the multimedia material for learning the material for pressure in liquid matter

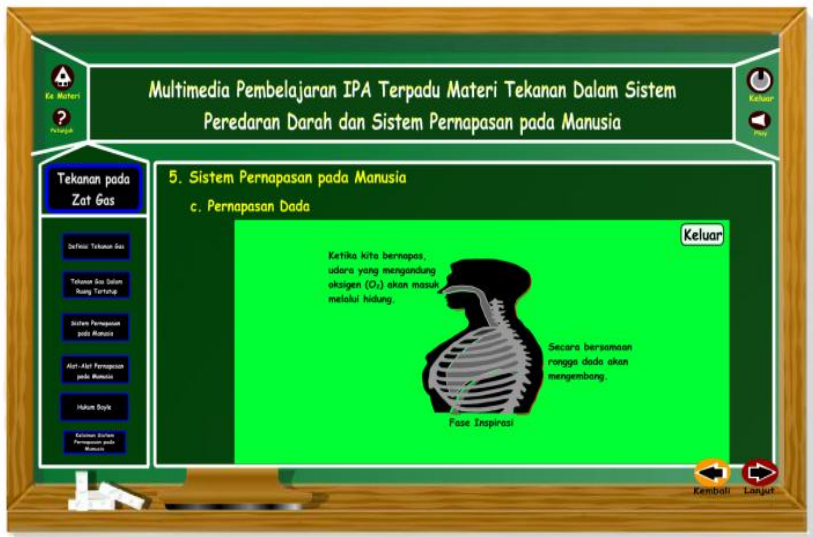

Figure 11 Display of the contents of the multimedia material on science learning in respiratory system material in liquid humans

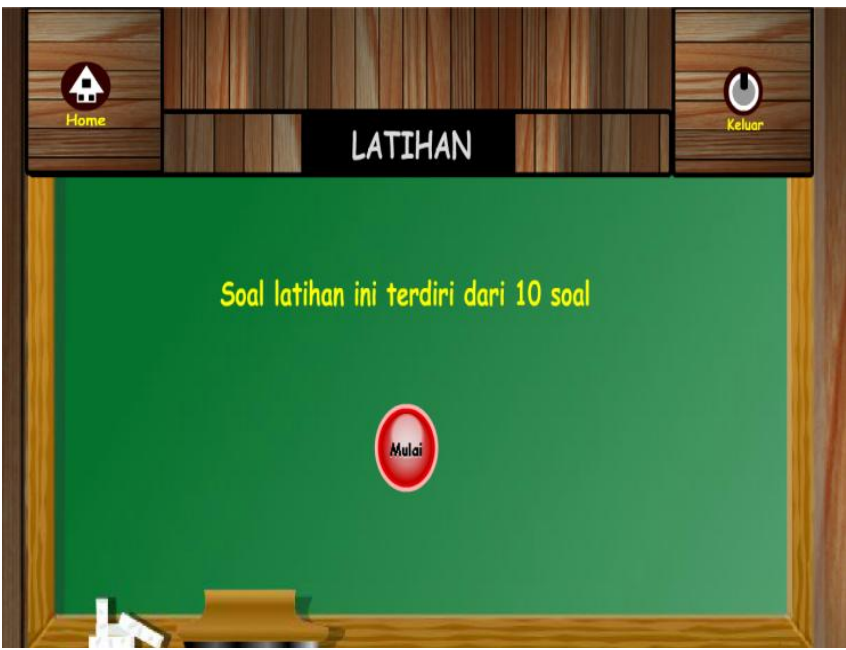

Figure 12 Display the opening pages of material science learning multimedia exercise pressure in the circulatory system and respiratory system in humans.

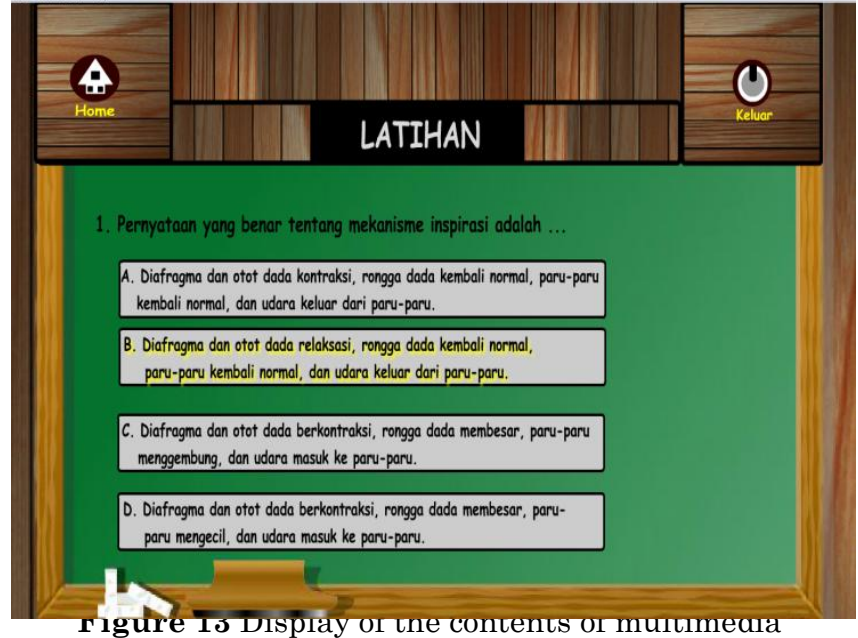

exercises on the material of pressure in the circulatory system and the respiratory

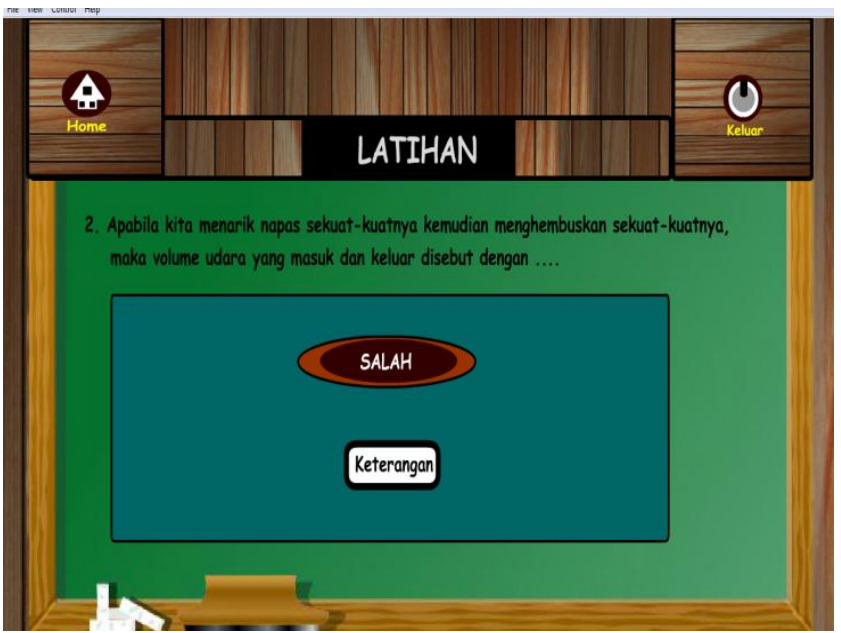

Figure 14 The display one of the critical answers pressure in the circulatory system and respiratory system in humans

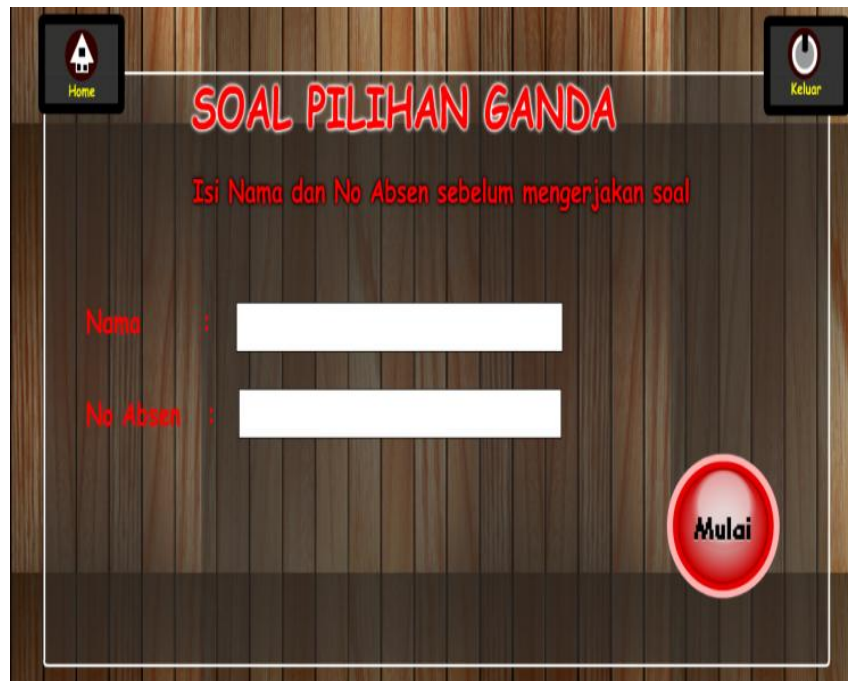

Figure 15 Display evaluation (multiple choice) multimedia learning material pressure in the circulatory system and respiratory system in human 


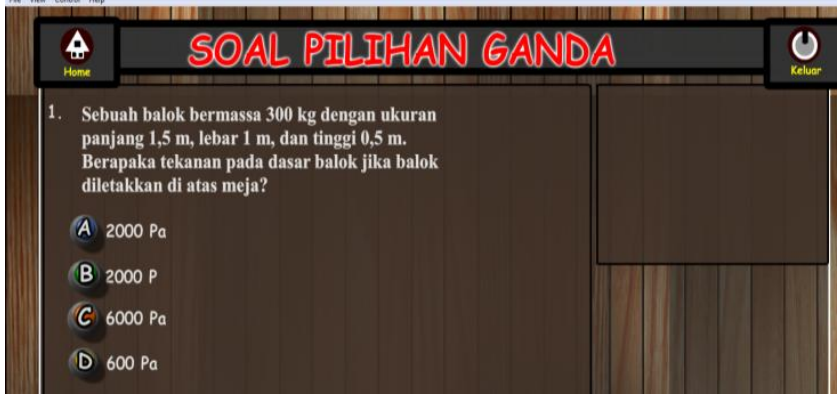

Figure 16 Display of multimedia evaluation questions

about learning material pressure in the circulatory system and the respiratory system in humans

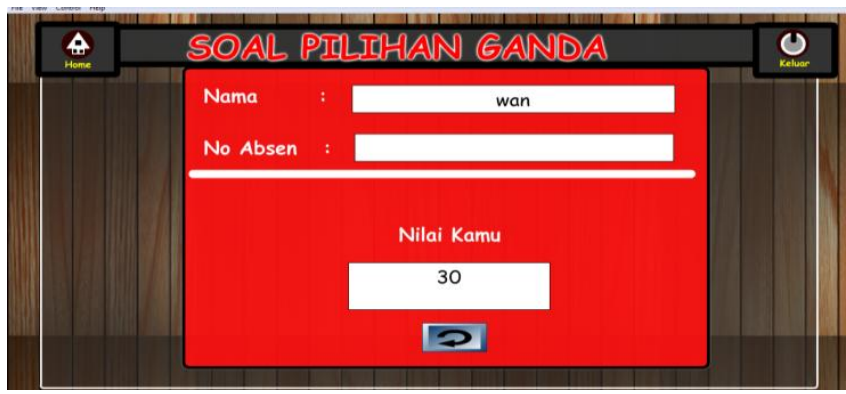

Figure 17 Display of the results of multimedia evaluation results

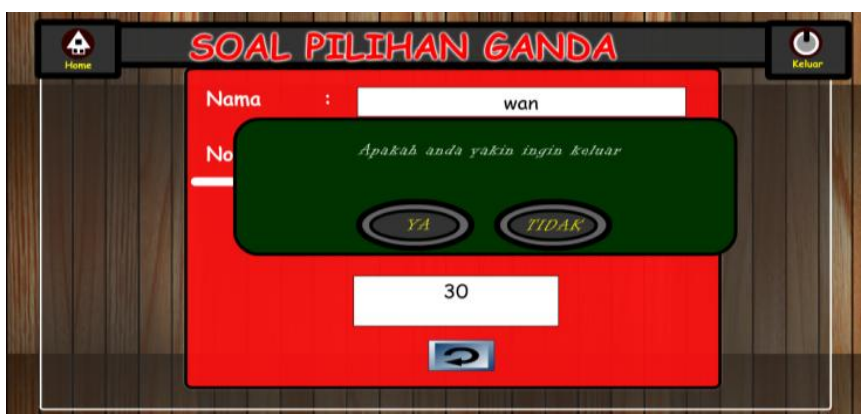

Figure 18 Display the menu log out multimedia

learning material pressure in the circulatory system and the respiratory system in humans

\section{Stage of Impementation}

This stage includes the stage of assessment by media experts, material experts, learning experts, and the implementation of limited trials this stage, validation, and verification is carried out on experts have appointed as media experts, material experts, and learning experts, respectively in the field of expertise and limited trials to obtain assessments, responses, suggestions, and enter what will be used as references for improvement. In this step, validation and testing will be carried out on multimedia products that have completed. Multimedia learning science products on pressure material in the circulatory and respiratory system in humans will be validated by two media experts, four material experts, two learning experts, and two teachers and 18 students. The results of expert validation written in Table 2 , Table 3 , and Table 4 .
Table 2. Data Results of Product Assessment by Learning Experts

\begin{tabular}{|c|c|c|c|}
\hline \multirow[t]{2}{*}{ Qualification Assessment } & \multicolumn{2}{|c|}{$\begin{array}{c}\text { Percentage of } \\
\text { Assessment (\%) } \\
\text { Expert }\end{array}$} & \multirow[t]{2}{*}{$\begin{array}{c}\text { Average of } \\
\text { percentage }(\%)\end{array}$} \\
\hline & 1 & 2 & \\
\hline \multicolumn{4}{|l|}{ Description } \\
\hline \multicolumn{4}{|l|}{ Curriculum / Learning } \\
\hline $\begin{array}{l}\text { 1. The accuracy of the material with core } \\
\text { competencies contained in the applicable } \\
\text { curriculum }\end{array}$ & 75 & 75 & 75 \\
\hline $\begin{array}{l}\text { 2. Compatibility of material with basic } \\
\text { competencies contained in the applicable } \\
\text { curriculum }\end{array}$ & 75 & 75 & 75 \\
\hline 3. Clarity of learning objectives & 100 & 75 & 87,5 \\
\hline $\begin{array}{l}\text { 4. The suitability of the order of material } \\
\text { contained in learning media with scientific } \\
\text { concepts }\end{array}$ & 75 & 75 & 75 \\
\hline 5. Clarity of learning media users & 75 & 100 & 87,5 \\
\hline $\begin{array}{l}\text { 6. Adequacy of material description in clarity of } \\
\text { scientific concepts }\end{array}$ & 75 & 75 & 75 \\
\hline 7. Adequacy of examples given & 75 & 75 & 75 \\
\hline 8. Material conformity with learning objectives & 100 & 100 & 100 \\
\hline 9. Clarity of learning instructions & 75 & 100 & 87,5 \\
\hline $\begin{array}{l}\text { 10. Ease of understanding sentences in } \\
\text { text/writing }\end{array}$ & 75 & 75 & 75 \\
\hline $\begin{array}{l}\text { 11. Ease of understanding material (content) } \\
\text { lessons }\end{array}$ & 50 & 75 & 62,5 \\
\hline 12. The accuracy of the order of presentation & 50 & 75 & 62,5 \\
\hline 13. Clarity of feedback/response & 50 & 75 & 62,5 \\
\hline $\begin{array}{l}\text { 14. Suitability of material with student } \\
\text { characteristics }\end{array}$ & 75 & 50 & 62,5 \\
\hline 15. Ease of media users & 75 & 100 & 87,5 \\
\hline 16. Interesting media used & 75 & 75 & 75 \\
\hline Final Percentage (\%) & & & 76,56 \\
\hline
\end{tabular}

From the data of expert learning assessment (Table II) on Adobe Flash CS6-based multimedia on pressure material in the circulatory and respiratory system in humans for grade VIII junior high school students, the final score is $76.56 \%$. Based on the validity criteria for the validity level assessment, the value of $76.56 \%$ is in the range of valid percentages (criteria Table 1).

Table 3. Data Results of Product Assessment by Material

\begin{tabular}{|c|c|c|c|c|c|}
\hline \multicolumn{6}{|c|}{ Expert } \\
\hline \multirow{3}{*}{ Qualification Assessment } & \multirow{2}{*}{\multicolumn{4}{|c|}{$\frac{\text { Percentage of Assessment (\%) }}{\text { Expert }}$}} & \multirow{3}{*}{$\begin{array}{c}\text { Average of } \\
\text { persentation (\%) }\end{array}$} \\
\hline & & & & & \\
\hline & 1 & 2 & 3 & 4 & \\
\hline \multicolumn{6}{|l|}{ Description } \\
\hline \multicolumn{6}{|l|}{ Topic } \\
\hline $\begin{array}{l}\text { 1. The truth of material } \\
\text { substance }\end{array}$ & 50 & 100 & 75 & 75 & 75 \\
\hline 2. Use of language & 75 & 75 & 75 & 75 & 75 \\
\hline $\begin{array}{l}\text { 3. Suitability of the } \\
\text { picture }\end{array}$ & 75 & 100 & 75 & 75 & 81,25 \\
\hline 4. Depth of material & 75 & 100 & 100 & 75 & 87,5 \\
\hline 5. Accuracy of examples & 75 & 75 & 100 & 75 & 81,25 \\
\hline 6. Truth response & 50 & 75 & 100 & 75 & 75 \\
\hline \multicolumn{6}{|l|}{ 7. Conformity tests with } \\
\hline $\begin{array}{l}\text { essential } \\
\text { competencies and } \\
\text { indicators }\end{array}$ & 50 & 100 & 100 & 75 & 81,25 \\
\hline $\begin{array}{l}\text { 8. Suitability test with } \\
\text { answer key }\end{array}$ & 50 & 100 & 100 & 75 & 81,25 \\
\hline \multicolumn{5}{|c|}{ Final Percentage (\%) } & 79,68 \\
\hline
\end{tabular}

From the material expert assessment data (Table 3) on Adobe Flash CS6 based science IPA on pressure material in the circulatory and respiratory system in humans for grade VIII junior high school students, the final score is $79.68 \%$. Based on the validity criteria for validity level assessment, the value of $79.68 \%$ is in the valid percentage range (criterion Table 1) 
Table 4. Data Results ff Product Assessment by Media Expert

\begin{tabular}{|c|c|c|c|c|}
\hline \multirow{3}{*}{\multicolumn{2}{|c|}{ Qualification Assessment }} & \multirow{2}{*}{\multicolumn{2}{|c|}{$\begin{array}{c}\text { Percentage of } \\
\text { Assessment (\%) } \\
\text { Expert }\end{array}$}} & \multirow{3}{*}{$\begin{array}{c}\text { Average of } \\
\text { Percentage } \\
(\%)\end{array}$} \\
\hline & & & & \\
\hline & & 1 & 2 & \\
\hline \multicolumn{5}{|c|}{ Description } \\
\hline \multicolumn{5}{|c|}{ 1. Display } \\
\hline & Menu display & 75 & 75 & 75 \\
\hline$b$ & Button usage & 75 & 100 & 87,5 \\
\hline c. & Type and size of text & 75 & 75 & 75 \\
\hline$d$ & Color composition & 75 & 75 & 75 \\
\hline \multicolumn{5}{|c|}{ e. Quality of photos, images, and } \\
\hline f. & Audio quality & 75 & 100 & 87,5 \\
\hline$g$ & Animation quality & 100 & 100 & 100 \\
\hline $\mathrm{h}$ & Ease of understanding to discuss & 75 & 100 & 87,5 \\
\hline i. & Quality of interaction & 75 & 75 & 75 \\
\hline j. & Attractiveness and motivation & 75 & 75 & \\
\hline \multicolumn{4}{|c|}{ Percentage Amount of final score } & 82,5 \\
\hline \multicolumn{5}{|c|}{ 2. Program } \\
\hline a. & Navigation & 75 & 100 & 87,5 \\
\hline b. & utton consistency & 75 & 75 & 75 \\
\hline c. & Clarity of instructions for use & 100 & 75 & \\
\hline d. & The efficiency of screen usage & 75 & 75 & 75 \\
\hline & Efficiency of text & 75 & 75 & 75 \\
\hline \multicolumn{4}{|c|}{ Percentage Amount } & 400 \\
\hline \multicolumn{4}{|c|}{ Final score } & 80 \\
\hline \multicolumn{4}{|c|}{ Total of Final score } & 162,5 \\
\hline \multicolumn{4}{|c|}{ Total Final Value } & 81,67 \\
\hline
\end{tabular}

From the data of media expert (Table 4) on Adobe Flash CS6 based science on the material of pressure in the circulatory and respiratory system in humans for grade VIII junior high school students the final score of $81.67 \%$. Based on the validity criteria for the validity level assessment, the value of $81.67 \%$ is in the valid percentage range (criterion Table 1).

Table 5. Data Results Try the Product by Teacher

\begin{tabular}{|c|c|c|c|}
\hline \multirow[t]{2}{*}{ Qualification Assessment } & \multicolumn{2}{|c|}{$\begin{array}{c}\text { Percentage of } \\
\text { Assessment (\%) } \\
\text { Teacher }\end{array}$} & \multirow{2}{*}{$\begin{array}{c}\text { Average of } \\
\text { Percentage } \\
\quad(\%)\end{array}$} \\
\hline & 1 & 2 & \\
\hline \multicolumn{4}{|l|}{ Description } \\
\hline \multicolumn{4}{|l|}{ Curriculum / Learning } \\
\hline $\begin{array}{l}\text { 1. Achievement of indicators and basic } \\
\text { competencies }\end{array}$ & 75 & 75 & 75 \\
\hline $\begin{array}{l}\text { 2. Conformity of material with } \\
\text { purpose/indicator }\end{array}$ & 75 & 75 & 75 \\
\hline 3. Clarity of study instructions & 75 & 100 & 87,5 \\
\hline $\begin{array}{l}\text { 4. Ease of understanding sentences in } \\
\text { the text }\end{array}$ & 50 & 100 & 75 \\
\hline $\begin{array}{l}\text { 5. Ease of understanding material } \\
\text { (content) lessons }\end{array}$ & 75 & 75 & 75 \\
\hline $\begin{array}{l}\text { 6. The accuracy of the order of } \\
\text { presentation }\end{array}$ & 75 & 75 & 75 \\
\hline 7. Adequacy of examples & 75 & 75 & 75 \\
\hline 8. Clarity of feedback/response & 75 & 100 & 87,5 \\
\hline $\begin{array}{l}\text { 9. Compatibility of material with student } \\
\text { characteristics }\end{array}$ & 50 & 75 & 62,5 \\
\hline 10. Ease of multimedia users & 75 & 75 & 75 \\
\hline 11. Attractive multimedia used & 75 & 100 & 87,5 \\
\hline
\end{tabular}

From the teacher assessment data (Table 5) on Adobe Flash CS6-based science material on the pressure in the circulatory and respiratory system in humans for grade VIII junior high school students, the final score was $77.27 \%$. Based on the qualification criteria for practicality assessment, the value of $77.27 \%$ entered in the possible percentage range (criteria Table 1).

Table 6. Data Results Try the Product by Students

\begin{tabular}{|c|c|c|c|c|}
\hline No & Questions & $\begin{array}{c}\text { Class of } \\
\mathrm{VIII}_{1}\end{array}$ & $\begin{array}{c}\text { Class of } \\
\mathrm{VIII}_{2}\end{array}$ & $\begin{array}{c}\text { Presentation } \\
\text { average } \\
(\%)\end{array}$ \\
\hline 1 & Display & 86 & 4,78 & 95,5 \\
\hline 2 & Use of buttons & 84 & 4,67 & 93,3 \\
\hline 3 & Clarity of button & 88 & 4,89 & 97,7 \\
\hline 4 & Text type and size & 80 & 4,4 & 88,8 \\
\hline 5 & Color suitability & 83 & 4,6 & 92,2 \\
\hline 6 & Image availability & 86 & 4,78 & 95,5 \\
\hline 7 & Use of images & 73 & 4,05 & 81,1 \\
\hline 8 & Use of animation & 86 & 4,78 & 95,5 \\
\hline 9 & $\begin{array}{l}\text { Ease of understanding } \\
\text { material }\end{array}$ & 71 & 3,9 & 78,9 \\
\hline 10 & $\begin{array}{l}\text { Ease of understanding } \\
\text { language }\end{array}$ & 88 & 4,89 & 97,7 \\
\hline 11 & $\begin{array}{l}\text { Use the navigation } \\
\text { buttons }\end{array}$ & 81 & 4,5 & 90 \\
\hline 12 & quality of interaction & 66 & 3,67 & 73,3 \\
\hline 13 & Use of multimedia & 87 & 4,8 & 96,7 \\
\hline 14 & Problem adequacy & 71 & 3,9 & 78,9 \\
\hline 15 & $\begin{array}{l}\text { Attractiveness and } \\
\text { motivation }\end{array}$ & 73 & 4,05 & 81,1 \\
\hline \multicolumn{4}{|c|}{ Final score } & 89,1 \\
\hline
\end{tabular}

Data from limited trial results by students (Table 6) Junior High School 8 Kendari on Adobe Flash CS6-based Science learning multimedia material on the pressure in the circulatory and respiratory system in humans for students obtained a final score of $89,1 \%$. The qualification criteria for practicality assessment, the value of $89.1 \%$ included in the possible range.

\section{Stage of Evaluation}

This stage is an assessment of the previous three phases: analysis, design, and development. This assessment carried out at the stage of implementation, previous an assessment by media experts, material experts, learning experts, teachers, and a limited trial of Adobe Flash CS6based science learning multimedia development products on pressure material in the circulatory and respiratory systems in humans for students Middle class VIII.

\section{CONCLUSION}

A description of the results of the analysis showed that results obtained material expert validation of $79.68 \%$, a media expert validation analysis results obtained for $81.67 \%$, and the results of validation analysis of learning experts obtained by $76.56 \%$. Based on these results, Adobe Flash CS6-based science learning multimedia categorized as feasible and practical used as learning multimedia 


\section{REFERENCES}

Aji, S. D., Hudha, M. N., Huda, C., \& Gufran, G. (2018). Computer Animation with Adobe Flash Professional Cs6 in Newton's Law. In IOP Conf. Series: Materials Science and Engineering 288 (pp. 1-4). https://doi.org /10.1088/1757-899X/288/1/012131

Ampera, D. (2017). Adobe Flash CS6-Based Interactive Multimedia Development for Clothing Pattern Making. In 1st International Conference on Technology and Vocational Teachers (ICTVT 2017) Adobe (Vol. 102, pp. 314-318). https://doi.org/10.2991 /ictvt/-17.2017.54

Arikunto, S. (2009). Prosedur Penelitian Suatu Pendekatan Praktik Edisi Revisi. Jakarta: Rineka Cipta.

Astatin, G. R., \& Nurcahyo, H. (2016). Developing Adobe Flash-Based Biology Instruction Media to Improve the Mastery of Competency in Curriculum 2013. Jurnal Inovasi Pendidikan IPA, 2(2), 165-175. https: //doi.org/10.21831/jipi.v2i2.10966

Augustyn, A. (2019). Interactive media. In Britannica Online Encyclopedia (pp. 1-2).

Branch, R. M. (2009). Instructional Design: The ADDIE Approach (1st ed.). London: Springer Science Business Media, LLC. https://doi.org/10.1007/978-0387-09506-6

Briggs, A., \& Sommefeldt, D. (2002). Managing Effective Learning and Teaching (1st ed.). London: Paul Chapman Publishing.

Chen, J., Wang, Z., \& Wu, Y. (2009). The application of flash in web-based multimedia courseware development. Interactive Technology and Smart Education, 6(4), 268-273. https://doi.org/10.1108/174 15650911009245

Fayanto, S., Sulisworo, D., Fathan, H., \& Istiqomah, N. (2019). The Implementation of Multimedia on Physics Learning Based on Direct Instruction Model in The Topic of Light. Indonesia Journal of Learning Education and Counseling, 1(2), 124-132.https:// doi.org/10.31960/ijolec.v1i2.94

Gagne, R. M., Wager, W. W., Golas, K. C., Keller, J. M., \& Russell, J. D. (2005). Principles of instructional design. Wadsworth Publishing (5th editio, Vol. 44). UK: Wadsworth Publishing. https://doi.org/10.1002 /pfi.4140440211

Iwan, M., \& Suyatna, A. (2018). Development of Static Fluid Learning Props to Improve Students , Argumentation Skills. International Journal of Research Granthaalayah, 6(June), 296-309. https://doi.org/10.5281/zenodo.1308 955

Muthmainnah, \& Imran, R. (2016). Analisis Kreativitas Guru dalam Penggunaan Metode Pembelajaran Sosiologi di Kelas X MAS Al-Jihad Pontianak. Jurnal
Pendidikan dan Pembelajaran Untan, 5(11), 1-13.

Othman, A., \& Wan Ahmad Jaafar Wan Yahaya. (2015). Multimeida Design Principles in Developing Multimedia Learning Application (MMLA). Jurnal Teknologi, 3(November), 7-12. https://doi.org/10. $11113 /$ jt.v75.5036

Perdiansyah, F., Supriyadi, Y., \& Astra, I. M. (2015). Pengembangan Media Pembelajaran Fisika dengan Program Adobe Flash CS6 Berbasis Keterampilan Proses Sains. Universitas Negeri Jakarta, pp. 206210.

Putra, M. I. S., Widodo, W., \& Jatmiko, B. (2016). The Development of Guided Inquiry Science Learning Materials to Improve Science Literacy Skill Of Prospective Mi Teachers. Jurnal Pendidikan IPA Indonesia, 5(1), 83-93. https://doi.org/10.15294/jpii.v5 i1.5794

Rezeki, S. (2018). Pemanfaatan Adobe Flash CS6 Berbasis Problem-Based Learning pada Materi Fungsi Komposisi dan Fungsi. Jurnal Pendidikan Tambusai, 2(4), 856-864. https://doi.org/10.31004/jptam.v2i4.33

Safitri, M. R., Budiharti, R., Ekawati, E. Y.(2014). Pengembangan Media Pembelajaran IPA Terpadu Interaktif dalam Bentuk Moodle. Jurnal Pendidikan Fisika, 2(1), 1-5.

Saselah, Y. R., Amir, M., \& Riskan, M. (2017). Interactive Multimedia Development Based on Adobe Flash CS6 Profesional on Learning of Chemical Equilibrium. Jurnal Kimia dan Pendidikan Kimia, 2(2),80-89. http://dx.doi.org/10.20961/jkpk.v2i2.11978

Shank, P. (2008). The Value of Multimedia in Learning. In R. Alm, B. Darnell, B. Sova, \& F. Investments (Eds.), Online Forums (1st ed., pp. 1-13). USA: The ELearnig Guild. 